ISSN 1984-3755

Licenciado sob uma Licença Creative Commons

\title{
Concílio Vaticano Il: tarefas pendentes para a Igreja no Brasil hoje ${ }^{1}$
}

\section{Vatican II Council: pending tasks for the Church in Brazil today}

\section{João Batista Libânio}

Doutor e mestre em Teologia pela Pontifícia Universidade Gregoriana, Roma; graduado em Teologia pela Hochschule Sankt Georgen, em Frankfurt;. ex-assessor do Instituto Nacional de Pastoral (INP), da CNBB, da Conferência dos Religiosos do Brasil (CRB), e dos Encontros Nacionais das Comunidades Eclesiais de Base; professor na Faculdade Jesuíta de Filosofia e Teologia, em Belo Horizonte, MG - Brasil, e-mail: jblibanio@cesjesuit.br

\section{Resumo}

O autor se propõe a indicar as tarefas pendentes para a lgreja no Brasil, no processo de recepção do Concilio Vaticano II. Antes, porém, de tratar delas, faz uma retrospectiva sobre o evento e sua trajetória nas últimas quatro décadas. São breves registros sobre o processo de preparação do Concílio, sua metodologia de trabalho, as turbulências nas últimas décadas, o entrecruzar-se de diferentes recepções e o paradoxo do pontificado de João Paulo II. Com relação às tarefas pendentes, segundo o autor, as maiores riquezas do Concilio vêm-lhe da inspiração, do espírito e do carisma. Entretanto, sua recepção padece de não pequeno deficit por causa da carência de institucionalização. Além disso, no espírito do Concílio, estamos

1 Texto apresentado no Seminário Nacional sobre os 40 anos do Vaticano II, realizado em Itaici, SP, em 2006, promovido pelo Instituto Nacional de Pastoral, organismo da CNBB. 
longe de assumir mais seriamente os desafios do diálogo inter-religioso, a chaga da exclusão, a sociedade pós-industrial do conhecimento e o flagelo das migrações.

Palavras-chave: Concílio. Contexto. Recepção. Institucionalização.

\begin{abstract}
The author intends to point the pending tasks for the Church in Brazil, in the process of reception of Vatican II Council. Before dealing with them, however, he looks back to the event and its trajectory in the last four decades. They are brief records of the preparation process of the Council, its working methodology, the turbulence of last decades, the interlacing of different receptions and the paradox of the pontificate of John Paul II. Regarding the pending tasks, according to the author, the greatest assets of the Council are brought by inspiration, by the Spirit and by the charisma. However, its reception suffers from a not-so-small deficit because of the lack of institutionalization. Moreover, in the spirit of the Council, we are far from taking the challenges of interreligious dialogue, the scourge of exclusion, post-industrial society of knowledge and the scourge of migration more seriously.
\end{abstract}

Keywords: Council. Context. Reception. Institutionalization.

\title{
Recordando o contexto
}

Falar de tarefas pendentes do Concílio Vaticano II requer, à guisa de introdução, rápido olhar sobre o seu evento e trajetória nesses 40 anos (1965-2005). A tese proposta soa: o Concílio Vaticano II foi uma realidade plural e paradoxal na preparação, na opção central metodológica, no desenrolar e na sequência. O gesto e o evento conciliares são mais que as decisões e textos.

\section{Na preparação}

A fissura que atravessa a história do Concílio começou com a Comissão Antepreparatória. Ela organizara um questionário longo e minucioso 
a ser enviado aos futuros membros do Concílio. Desta maneira, já se condicionavam as respostas conforme a mente da comissão. João XXIII optou por outra via. O Secretário de Estado enviou uma carta pela qual o Papa mostrava o desejo de "conhecer opiniões e pareceres e recolher conselhos e vota dos exmos. bispos e prelados que são chamados de direito a participar do Concílio Ecumênico (cân. 223). De fato, Sua Santidade atribui a maior importância aos pareceres, conselhos e vota dos futuros Padres conciliares; o que será muito útil na preparação dos temas para o Concílio" (BEOZZO, 2005, p. 16). Outros pontos da preparação revelam essa mesma tensão, como a presidência das Comissões preparatórias confiada a membros da Cúria com a presença de teólogos e bispos de outra visão teológica, o corte entre bispos curiais e pastorais, a existência concomitante de duas estruturas de Igreja de âmbito universal - a Cúria e as comissões conciliares.

A lei da inércia funciona no campo físico e psicossocial. Os Concílios, ao longo da história da Igreja, associaram-se a crises especialmente quanto a verdades dogmáticas com a finalidade de condenar as heresias. A boca torta do cachimbo eclesiástico já apontava para um clima de caça às bruxas. E as havia em quantidade soltas na sociedade e dentro da Igreja. João XXIII propunha-se outra finalidade na linha pastoral. Algo inédito.

\section{Opção central metodológica e desenrolar}

Com a morte de João XXIII, coube a Paulo VI reorientar o Concílio. Sem afastar-se do Oriente do papa anterior, marcou-o com seu espírito conciliar, equilibrando-se entre forte surto renovador e resistência conservadora. Optou pela via do consenso majoritário. Queria que os textos conciliares fossem aprovados por larga maioria a fim de não aparecer diante da Igreja e do mundo como se uma ala eclesiástica vencesse a adversária.

A imagem da Igreja conservava assim a unidade fundamental. Os arranhões ideológicos, teológicos e disciplinares não chegavam a ferir-lhe e deformar-lhe a face. Pagou-se, porém, o preço dessa tensão e ambiguidade do texto a ponto de A. Acerbi falar das duas concepções de Igreja coexistentes nos textos do Concílio. Isso se tornou chave de leitura dos textos conciliares. 
No desenrolar, essa metodologia produziu tensões (MELLONI, 2005, p. 34) $)^{2}$. Houve momentos de euforia por parte dos progressistas: a intervenção de João XXIII retirando o esquema de "As Duas Fontes", a votação da inserção do esquema sobre a Virgem Maria no esquema sobre A Igreja, a criação do capítulo a respeito do Povo de Deus antes da hierarquia, a ideia de uma Constituição pastoral tratando da relação Igreja e mundo, e muitos outros. Em dado momento de entusiasmo, Y. Congar, ao considerar a importância do Secretariado para União dos Cristãos e a relevância atual do ecumenismo católico na cúpula, anotou em seu diário do Concílio no dia 11 de maio de 1965: "É fantástico! Deu-se o passo!" (CONGAR, 2002, p. 378). No entanto, em outra circunstância, E. Fouilloux refere-se à "semana negra" em que se freou a liberdade religiosa, o Decreto sobre o Ecumenismo foi podado, quase definiram à revelia do Concílio o título de Maria Mãe da Igreja e foi imposta a nota explicativa (MELONI, 2005, p. 36, 460).

\section{Turbulências das últimas décadas}

Os anos seguintes ao Concílio passaram por turbulências de voos transatlânticos tanto fora como dentro da Igreja. Basta acenar para Maio de 1968, o crescimento das esquerdas com o doloroso desfecho da queda do socialismo (1989), o desmantelamento do Estado do bem-estar social com tristes perdas sociais, o surgimento do poderoso neoliberalismo e uma sociedade pós-industrial altamente conflituosa.

No interior da Igreja, a rapidez das mudanças e a explosão de experiências inovadoras em diversos campos da vida eclesial, a diminuição do acatamento da autoridade central assustaram Paulo VI, bispos e grupos tradicionais. Dois fatos visualizaram esse surto incoercível e tocaram, de modo especial, o coração do Papa: a saída de uns 30 mil sacerdotes do ministério e a reação hostil de setores eclesiásticos importantes à Encíclica Humanae vitae, sem falar da opinião pública mundial.

2 Nas páginas 34/458-459/483 desse número da Concilium se encontram exemplos dessa tensão permanente. 
Mais tarde, por ocasião dum balanço sobre os anos pós-conciliares, o Osservatore Romano informa que "o Santo Padre afirma ter a sensação de que "por alguma fresta entrou a fumaça de Satanás no Templo de Deus" (PAULO VI, 1972, p. 2). Aí estão a dúvida, a incerteza, a problemática, a inquietação, a insatisfação, o confronto".

Também na Igreja reina este estado de incerteza. Acreditava-se que depois do Concílio viria um dia de sol para a história da Igreja. Veio, ao invés, um dia de nuvens, de tempestade, de escuridão, de procura, de incerteza. Pregamos o ecumenismo e nos afastamos sempre mais dos outros. Procuramos cavar abismos em vez de fechá-los (PAULO VI, 1972, p. 2).

Forças conservadoras agiram todo o tempo pós-conciliar. A oposição maior assumiu forma cismática e se chamou Mgr. Lefebvre com ramificações no Brasil na diocese de Campos. Sem chegar a tal paroxismo, grupos de resistência alardeavam os riscos, os abusos e os perigos. Mantiveram-se firmes, obstando as inovações. Recorreram a um estratagema jurídico. O Concílio Vaticano II, ao proclamar-se pastoral, foi interpretado por eles sem força vinculante. E devia ser entendido à luz dos Concílios dogmáticos anteriores de Trento e Vaticano I.

\section{Entrecruzar-se de três recepções}

Aconteceu um entrecruzar-se de três recepções. A recepção tridentina ainda prosseguia seu caminhar por meio da revitalização da face visível da Igreja na prática dos sacramentos, no ensinamento objetivo da doutrina e no reforço do lado institucional e jurídico. Tal se fazia à custa do encurtamento da teologia da graça, do primado da Palavra, da experiência pessoal.

Mais recente se sobrepunha à recepção tridentina o movimento desencadeado pelo Concílio Vaticano I. A instituição visível da Igreja sofria pesados ataques das forças políticas nascidas da Revolução francesa. A figura do Papa via-se no centro das investidas. A recepção do Vaticano I reforça especialmente o magistério pontifício, ao definir-lhe o primado e a infalibilidade. 
A caminhada do Concílio Vaticano II entremeia-se com as anteriores num duplo movimento conflituoso de inovação e resistência. Mentalidades rígidas e esclerosadas não permitiam as mudanças e os avanços.

$\mathrm{E}$, de fato, ao longo desses anos, o encontro das diferentes recepções tem produzido quatro figuras de realização do Vaticano II. Uma primeira tem-se concentrado na leitura literal dos textos do Concílio com a dificuldade de interpretar um texto com afirmações, senão contraditórias, ao menos paradoxais. Outros selecionaram alguns textos segundo sua pré-compreensão ideológica e teológica pré-moderna, vestindo a rigidez tridentina com alguns traços originais do espírito do Vaticano II.

Outros não esconderam a nostalgia do passado. Bloquearam os dinamismos suscitados pelo Concílio com medo de comprometer a "identidade tridentina" anterior que defendiam sem rebuço. Batalhavam pela sua manutenção lá onde ainda existia e pela sua reconstituição lá onde tinha sido demolida. O arcebispo francês Mgr. Lefebvre e seus adeptos propugnavam tal recepção intemeratamente.

Uma terceira recepção concentrou-se em captar-lhe as inovações, o espírito original, os elementos novos para caminhar para decisões e concretizações além da letra. Abriu-se ao futuro num mundo de plena ebulição. Percebeu a autenticidade do Concílio como resposta corajosa e aberta às situações diferenciadas. Medellín exemplifica essa recepção criativa por parte das Igrejas pobres.

Vieram outros que radicalizaram o processo de mudança iniciado pelo Vaticano II. Levaram-no até as últimas consequências de propugnar uma implosão da forma histórica atual do Cristianismo e, com ele, naturalmente, a das Igrejas cristãs.

\section{Paradoxo do Pontificado de João Paulo II}

A recepção sofreu o impacto do longo e marcante pontificado de João Paulo II cujo balanço desafia os analistas. A fim de entender melhor as tarefas pendentes, apontaremos alguns pontos mais ou menos consensuais sobre esse período da vida da Igreja.

No fim do Pontificado de Paulo VI, a Igreja católica, tanto em amplos setores do católico médio como da hierarquia, sentia-se temerosa 
pela inquietação teológica e disciplinar no seu interior. Alguns analistas já detectaram, desde 1968, um esforço do Papa para conter a efervescência preocupante. Mas fora insuficiente. A Teologia moderna liberal europeia e a teologia da libertação do Terceiro Mundo abalavam a tranquilidade dos rincões teológicos conservadores. Grandes ordens religiosas assumiam uma liberdade no pensar e agir que contrastavam com a docilidade de outros tempos. No campo da Moral, especialmente nos Estados Unidos, a Teologia avançava resolutamente para novas posições, percebidas como altamente questionáveis à luz dos ensinamentos oficiais. Enfim, a liturgia, a vida consagrada, a pedagogia dos colégios e universidades católicas, a pastoral ensaiavam experiências, algumas arriscadas.

Nesse contexto, elegeu-se como Papa, João Paulo II, em pleno vigor de forças, psíquicas e espirituais. Assumiu com coragem a tarefa de serenar esses movimentos do interior da Igreja e lançar amplo projeto evangelizador a fim de deter o fluxo de saída da Igreja, sobretudo na Europa e de reconquistar os egressos e de avançar para novas fronteiras.

João Paulo delineou o núcleo do projeto evangelizador, que receberá mais tarde o nome de "Nova Evangelização" ou "Reevangelização", na Encíclica programática Redemptor hominis: a centralidade de Jesus na face da Igreja. Em outro momento, o Papa incentivou 10 mil universitários da Comunhão e libertação em termos que concretizavam tal projeto.

Vocês dizem que a libertação que o mundo deseja é o Cristo. Cristo vive na Igreja. A verdadeira libertação do homem vem, por conseguinte, da experiência da comunhão eclesial. Construir esta comunhão é, pois, a contribuição essencial que o cristianismo pode oferecer para a libertação de todos (URQUHART, 2002, p. 201).

Mais visível se tornou o paradoxo na distância entre os gestos proféticos de João Paulo, a geografia das viagens, a gigantesca personalidade humana e midiática, e uma série de intervenções dogmáticas e disciplinares. Em ambos os casos, apelava-se para o Vaticano II, aparecendo aí aquela ambivalência de que se falou anteriormente na preparação, desenrolar e confecção dos textos conciliares. O polo horizontal da acolhida e do anúncio do

3 Discurso de João Paulo II a 10 mil universitários da CL, março 1979. 
evangelho literalmente até os confins da Terra contrastava com a centralização do poder e com a resistência silenciosa da burocracia eclesiástica. Consequentemente houve enfraquecimento das instituições intermédias e participativas das conferências episcopais, das igrejas particulares. Infiltrou-se lenta, mas de modo crescente, um clima de medo, de subserviência, de mediocridade, de carreirismo, de vaidades e ambição pelos pequenos dentes da engrenagem eclesiástica. $\mathrm{H}$. Arendt pinta o extremo do processo e discurso burocrático que transformou um funcionário normal no monstro de Eichmann (ARENDT, 2001). Vale a pena compulsarmos esse escrito para defender-nos do risco de envolver-nos com uma atitude que se situa no lado oposto do Evangelho.

\section{Institucionalização do carisma do Vaticano II}

Entrando diretamente no tema, propomos uma primeira tese: as maiores riquezas do Concílio vêm-lhe da inspiração, do espírito e do carisma e, por sua vez, sofre de não pequeno deficit por causa da carência de institucionalização. Cabe-lhe ainda essa tarefa.

\section{Carisma no Vaticano II}

\section{Esclarecimento conceitual}

O Vaticano II foi fundamentalmente carisma. Brevemente distinguimos dois momentos culturais que configuraram diferentemente a compreensão de carisma.

Nos idos de 1960, carisma como força esperançosa de mudança interna da Igreja e como sua presença transformadora na Sociedade. No ar, respiravam-se os ingredientes que explodiram com o movimento Maio de 1968. As pessoas sentiam-se imersas na realidade, fazendo história num tríplice movimento. Recordemos do Festival de 1968, em que Geraldo Vandré teve sucesso vulcânico com a composição "Pra não dizer que não falei de flores", cujo refrão resumia intuitivamente o espírito da época: 
"Vem, vamos embora que esperar não é saber/Quem sabe faz a hora não espera acontecer". Saber, conhecer a cultura tradicional não é esperar. Não é isso que se quer. Está embutido um sentido de destradicionalização e de desinstitucionalização, refletindo desafeição e descrédito em face das instituições. O passado já passou, como disse ironicamente um jovem ao Presidente Costa e Silva. Trata-se de construir o presente com a ideologia e utopia do futuro. O carisma desencadeava força e coragem para mudar a realidade presente, sonhando com um futuro melhor. Por esse futuro sacrificavam-se prazeres presentes.

Nos tempos atuais, carisma mudou de cara. Envolve-se num clima emocional, alimentado pela mídia. Volta-se para a felicidade e bem-estar individual. O prazer e o gozo são-lhe os combustíveis. O passado não lhe importa. O futuro nem mesmo existe. Manifesta descompromisso com o futuro. Substitui a ética pela estética, o empenho e a luta comprometida pela festa.

O Vaticano II vivenciou o carisma na perspectiva do anúncio de uma realidade nova com o concomitante agir na sua construção. A palavra mágica da práxis enchia as bocas de esperança e alegria.

\section{Aspectos do carisma do Vaticano II}

Em Pio XII, a Igreja católica estendera a distância entre a hierarquia e o povo ao extremo. O cortejo que acompanhava a entrada do Papa na Basílica nas celebrações simbolizava a sua soberania. Só quem vivenciou tal cena consegue hoje imaginá-la. A simples enumeração dos seus componentes impacta: soar das trombetas de prata, o Pontífice com tiara, luvas e sapatos da cor litúrgica, carregado na sedia gestatória por sediários vestidos a rigor, cercado de flabelli (carregavam imensos leques) e uma multidão de cortesãos eclesiásticos e civis vestidos segundo sua função. Assemelhava-se à corte imperial de tempos idos (DORÉ, 2005, p. 174).

O Vaticano II provoca a quinada copernicana. Estabelece a base laical (de $\lambda \alpha o ́ s=$ povo) da Igreja, ao fazer anteceder ao capítulo sobre a hierarquia longa reflexão sobre o Povo de Deus. Todos somos Igreja pelo batismo. Estatui-se uma igualdade radical na Igreja que retoma um 
dos ensinamentos principais de Jesus: "Entre vós não seja assim. Ao contrário, quem quiser ser grande, seja vosso servidor, e quem quiser ser o primeiro, seja vosso escravo. Foi assim que o Filho do homem veio: não para ser servido mas para servir e dar sua vida em resgate de muitos" (Mt 20,26). K. Rahner, que esteve na origem de muitas dessas intuições, avança mais dizendo que a humanidade é povo de Deus, orientada para a Igreja. Valoriza-se a Igreja particular. Abre-se ao fiel comum o acesso à Escritura, seja colocando-lhe nas mãos boas traduções, divulgando e vulgarizando as pesquisas dos exegetas. Afirma-se o primado inconteste da Palavra de Deus na vida do cristão, aproximando-nos dos protestantes. Revitaliza-se a liturgia segundo o princípio da inteligibilidade, ao promover participação consciente e compreensão do fiel comum. Respeita-se o caráter pluricultural dos participantes. Valoriza-se a experiência do cristão nos diversos setores, antes de imporem-se-lhes ensinamentos e normas extrínsecas. Amplia-se a compreensão do caminho da santidade até então restrito aos religiosos. Enfim, a valorização da dimensão humana recebe nas palavras de Paulo VI no discurso de encerramento do Concílio nítida chancela: "para conhecer a Deus é necessário conhecer o homem". A base laical e humana da realidade teologal da Igreja e da compreensão da Revelação alça-se à chave interpretativa dos textos conciliares. A. Torres Queiruga chama atenção para o fato de que, desde o começo, na Dei Verbum, o Concílio reconhece a "implicação constitutiva da acolhida humana para a mesma Revelação divina" (QUEIRUGA, 2005, p. 27).

A intuição laical de igualdade desdobra-se na ideia de colegialidade. Entre iguais, a maneira de governar não se faz pela imposição, mas pela busca colegial de consensos. O Concílio começa de cima para baixo, pensando a colegialidade episcopal dos bispos entre si e com o Papa. Mas ela se estende a todos os segmentos da Igreja até lá embaixo nas pequenas comunidades. Significa uma revolução na eclesiologia até então fortemente piramidal e monárquica. Com isso, os órgãos intermédios e colegiados adquirem importância para a vida da Igreja: Conferências episcopais, Sínodos dos Bispos, Sínodos diocesanos, Sínodos continentais Conselhos pastorais, Conselhos regionais, forâneos, paroquiais e comunitários e outras possíveis instituições intermediárias. 
O carisma do Vaticano II não se prende à interioridade da Igreja. Num gesto audaz e único na história da Igreja, escreve uma Constituição Pastoral sobre a Igreja no mundo de hoje. Texto tão inusitado que o termo "pastoral" careceu de nota explicativa. Esta deixa filtrar a ideia de que, mesmo ao tratar de "princípios doutrinais" e de "elementos imutáveis", o texto contém elementos transitórios. Rompe-se uma tradição de permanecer unicamente nos princípios absolutos, imutáveis, ao abordar questões e problemas de maior urgência da atualidade. Desafia a teologia do Concílio a tarefa de articular corretamente a relação dialética entre universalidade e particularidade, entre o absoluto dos princípios e a abertura para a diversidade da situação presente.

Logo no primeiro parágrafo, a Gaudium et spes abre um horizonte insuspeitado, ao identificar as alegrias e as esperanças, as tristezas e as angústias dos discípulos de Cristo com as dos homens e mulheres de hoje, sobretudo com as dos pobres e de todos aqueles que sofrem. O pórtico dessa Constituição mostra o espaço em que o cristão se encontra. Toda realidade humana lhe ressoa no coração, ligando-se visceralmente ao gênero humano e a sua história. Embora discreta, em tom menor, a presença do pobre incisa a carne do texto.

\section{Deficit de institucionalização}

\section{Necessidade da institucionalização do carisma}

As intuições carismáticas do Vaticano II fizeram vibrar os ânimos nos anos seguintes. João XXIII anunciara um Pentecostes. Algo daquela experiência arquetípica se deu. Mas, em seguida, se percebeu como M. Weber tinha razão. O carisma rompe com certa institucionalização, quebra estruturas, aquece a frieza burocrática. Perder-se-á no vazio, se não se institucionalizar, se estruturar, encontrar canais jurídicos e até mesmo burocráticos. Do contrário, as belas ideias, os bons desejos, os ideais proclamados ficam entregues à boa-vontade de pessoas da instituição que os assumem e concretizam. Mas aqueles que se negam, conseguem asfixiar o sopro vital do carisma. Foi isso que aconteceu com os traços carismáticos fundamentais do Concílio. Naturalmente certa institucionalização se conseguiu. 


\section{Tentativas limitadas}

No entusiasmo da colegialidade, Paulo VI instituiu o Sínodo dos Bispos que até hoje está a reunir-se. Deu-se um passo. Bispos do mundo inteiro se congregam para discutir um tema relevante para a vida da Igreja, depois de um processo preparatório de certa duração. Agita-se na consciência da Igreja questão importante. Da base da Igreja sobem vozes até as alturas romanas. J. Doré percebeu nessa prática realização parcial do ideal de conciliaridade (DORÉ, 2005, p. 181).

Mas ficou-se a meio caminho. Os temas vêm pré-determinados por Roma. O Sínodo dispõe somente de voz consultiva. As proposições que os bispos formulam, até o último Sínodo, eram entregues, de modo confidencial, ao Papa para que ele, depois, escrevesse a Exortação apostólica pós-sinodal, pinçando as sugestões que lhe aprouveram. A figura do Sínodo se esvaía sob a pesada autoridade pontifícia.

A confecção do Novo Direito Canônico pretendeu ser ampla institucionalização do Vaticano II. Duvida-se de que ele realmente conseguiu dar corpo às intuições carismáticas e utópicas do Concílio. Teme-se que as atenuou, recorrendo a textos conciliares devedores antes a fontes conservadoras. Certamente persistem, em forma de desejo, muitas das inovações conciliares que carecem de canais de circulação. São tarefas pendentes.

\section{Tarefa pendente da institucionalização}

\section{Estabelecer os princípios de institucionalização}

Não basta canalizar o carisma para dentro de instituições. Facilmente se reproduzem formas arcaicas e ultrapassadas. Num primeiro momento, esse processo de rotinização e institucionalização implica estatuir alguns princípios orientadores.

Atravessa vários textos conciliares a consciência de manter nos diversos campos da vida eclesial a relação dialética entre universalidade e particularidade, entre o absoluto dos princípios e a abertura à diversidade. Isso significa difícil equilíbrio entre a intransigência e o relativismo, entre o apego a 
expressões concretas e o descaso por qualquer uma delas. Em termos teóricos e abstratos, já há consenso sobre esse princípio. A dificuldade acontece no discernimento concreto, medindo até onde se cede ou não a um dos extremos.

A pós-modernidade e a sociedade pós-industrial pedem cada vez mais flexibilidade, leveza, criatividade, mobilidade institucional graças à rapidez das transformações e ao tipo de cultura informatizada. Esta permite gigantesca velocidade de circulação de informações e de produção de realidades virtuais.

No mesmo sentido, impõe-se o princípio da inteligibilidade que exige transparência e justificação por parte da instituição de suas decisões. Pesa sobre procedimentos sigilosos enorme suspeita de corrupção e de conivência com o crime. A imprensa vigia permanentemente as instituições, denunciando qualquer jogo secreto. E a Igreja católica tem sofrido bastante no referente aos casos de desvios sexuais de membros do clero, acusada de ocultá-los. Decisões arbitrárias e autoritárias geram sempre maior repulsa. E as estruturas eclesiásticas necessitam acostumar-se a passar pelo crivo da transparência.

A Doutrina Social da Igreja defende o princípio de subsidiariedade. Falta-lhe impregnar dele a sua própria expressão institucional, por meio de consistente descentralização. Sob esse aspecto, toca às Igrejas regionais e particulares a tarefa de ajudar o poder central a perceber os equívocos da atual centralização em termos religiosos, culturais e até econômicos. Em âmbitos seculares, cresce o fenômeno da terceirização e da franquia, versões atualizadas da subsidiariedade.

Pertence ao cerne da mensagem de Jesus o espírito igualitário, formulado por Paulo sob diversas formas: "Pois num só Espírito todos nós fomos batizados para sermos um só corpo e todos, quer judeus, quer gregos, quer escravos, quer livres, bebemos do mesmo Espírito" (1Cor 12,13). "Então não haverá nem judeu nem grego, nem bárbaro nem cita, nem es-

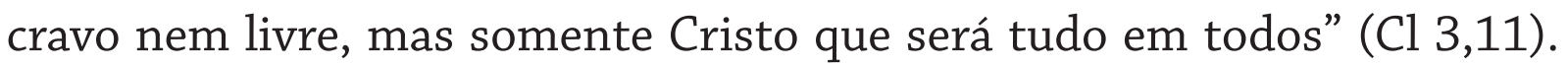
"Já não há judeu nem grego, nem escravo nem livre, nem homem nem mulher, pois todos vós sois um em Cristo Jesus" (Gl 3,28). O exegeta J. D. Crossan trabalha esse espírito igualitário de Jesus sob a forma de comensalidade. Considera essa prática de Jesus extremamente original e revolucionária em seu tempo (CROSSAN, 1994, 1995). 
E infelizmente essa mensagem, uma vez recuperada por forças seculares políticas, recebeu a oposição da Igreja. Faltou-lhe lucidez para perceber nela a fotografia de seu Mestre.

Puebla formulou tal espírito igualitário sob o binômio "comunhão e participação" e o Sínodo de 1985 propôs a categoria "comunhão" como chave hermenêutica fundamental para o Vaticano II. Em termos práticos, significa buscar nas decisões no interior da Igreja um consenso diferenciado, sem abolir a diversidade de experiências.

Tanto mais se impõe esse espírito igualitário quanto mais cresce o autoritarismo até mesmo no clero jovem (BENEDETTI, 1999). Raízes psicanalíticas e socioculturais permitem entender o fenômeno da insegurança de pessoas pouco inteligentes e, de pouca cultura, incorporadas ao clero, em face de um mundo plural, complexo e hostil. Reações de autoritarismo, fundamentalismo e voluntarismo vêm suprir a falta de segurança pessoal e inteligência cultivada.

Subjaz a esse espírito de igualdade uma compreensão da Igreja como comunidade da liberdade e não da necessidade ou obrigatoriedade. Exige, por sua vez, reinterpretação da concepção do poder divino da autoridade eclesiástica. A. Torres Queiruga sugere pensar o poder na Igreja à luz do que João XXIII escreve na Pacem in Terris do poder civil (JOÃO XXIII, 1963, n. 52 apud QUEIRUGA, 2005, p. 32).

Pelo fato, porém, de a autoridade provir de Deus, de nenhum modo se conclui que os homens não tenham faculdade de eleger os próprios governantes, de determinar a forma de governo e os métodos e a alçada dos poderes públicos. Segue-se daí que a doutrina por nós exposta é compatível com qualquer regime genuinamente democrático.

\section{Prática vigente da institucionalização}

E depois do Vaticano II, que prática de institucionalização de seu espírito e carisma está em curso? Percebe-se a existência ainda da resistência das antigas estruturas. O novo causa medo. E os dois pontificados seguintes ao Concílio deixaram uma herança ambivalente como os analistas constatam e como já nos referimos anteriormente. Permitiram e introduziram 
elementos estruturantes no espírito novo do Concílio, mas também conviveram com reações opostas.

Que de novo surgiu e está a surgir para prosseguirmos as tarefas pendentes? Em termos eclesiológicos na América Latina, as Comunidades eclesiais de base (CEBs) encarnam os princípios do Concílio. Existe sobre elas ampla bibliografia. Indicam-se aqui alguns poucos traços significativos que visibilizam a sua novidade conciliar. Superam o anonimato e o isolamento das estruturas tradicionais, quer na Igreja quer na sociedade, favorecendo uma relação subjetiva e intersubjetiva. Articulam fé e compromisso, evitando a dicotomia entre ambas e o unilateralismo militantista.

$\mathrm{Na}$ já conhecida distinção de Pedro A. Ribeiro de Oliveira, Igrejas particulares assumiram ser uma Igreja com $C E B$ s e outras poucas de CEBs. As primeiras contam com a existência de CEBs em seu território. As outras se moldaram e se configuraram no conjunto de suas estruturas segundo o modelo das CEBs (OLIVEIRA, 1997, p. 121-175). Na linha do espírito participativo, comunitário e igualitário, as CEBs têm encontrado uma dupla forma de coordenação nacional. Uma Comissão Ampliada acompanha-as com subsídios e promoções de encontros. E, em intervalos, ultimamente mais longos, promovem-se Encontros Intereclesiais de CEBs que se lhes tornaram ponto de referência para a caminhada (TEIXEIRA, 1996) a modo de um concílio da Igreja das e nas bases.

$\mathrm{Na}$ perspectiva de futuro, permanece o desafio de pensar uma Igreja como rede de comunidades e as Igrejas de uma região, como rede de Igrejas. A concepção "monárquica" do bispo e do pároco dificulta tal tarefa. No entanto, a crescente mentalidade de rede tem condições de produzir novo modelo eclesiológico, respeitando a ordem sacramental. As redes se constituem tanto por áreas geográficas quanto por interesses. Além das redes reais, em tempo e espaço circunscriptivo, abre-se um campo ainda apenas explorado pela pastoral das redes virtuais com uso da Internet e outros recursos de natureza similar. Estas funcionam on line e gozam de ubiquidade inimaginável. Haja vista o exemplo de Partenia, a "Diocese sem fronteira" do bispo francês J. Gaillot, de realidade virtual ${ }^{4}$. Algo absolutamente inédito até então que rompe barreiras

4 Sua “diocese virtual” está disponivel em: <www.partenia.org>. 
ancestrais e anuncia possibilidades impensáveis para a evangelização e vida eclesial.

João Paulo II considerava os movimentos de espiritualidade e apostolado de leigos como um dos brotos espirituais e promissores do Concílio. O cardeal Ratzinger, então Prefeito da Congregação para a Doutrina da Fé, exprimiu-se várias vezes de maneira entusiasta sobre "o aparecimento de novos movimentos que ninguém previu, mas que brotaram espontaneamente da vitalidade interior da fé mesma", "algo como um período de Pentecostes na Igreja” (RATZINGER; MESSORI, 1985, p. 27). Trouxeram novo vigor à Igreja. Embora tenham entrado em choque com algumas igrejas locais, o Cardeal Ratzinger interpretou tal fato como consequência do zelo juvenil e entusiasta de tais movimentos em contraste com a lentidão e acomodação estrutural de certas igrejas locais (RATZINGER, 1988, p. 400).

Respeito à América Latina, Santo Domingo reafirmou o protagonismo dos leigos, recordando-lhes a missão de presença renovadora no interior da Igreja, mas sobretudo no mundo da tecnociência, da modernidade avançada. É-lhes demandada melhor formação biblicoteológica, pastoral e espiritual.

Anuncia-se o milênio do leigo. A Igreja, especialmente na Europa onde o clero e a vida religiosa minguam a olhos vistos, aposta para sua sobrevivência na criatividade dos fiéis cristãos, apoiada no "direito de fundar e dirigir livremente associações para fins de caridade e piedade, ou para favorecer a vocação cristã no mundo, e de se reunirem para a consecução comum dessas finalidades" (CIC ${ }^{5}$, n. 215). E o cânone seguinte reafirma que "todos os fiéis, já que participam da missão da Igreja, têm o direito de promover e sustentar a atividade apostólica, segundo próprio estado e condição, também com iniciativas próprias". O consentimento da autoridade eclesiástica competente se faz necessário para que os fiéis reivindiquem para sua iniciativa o nome de católica. Apesar dessa limitação, o Direito Canônico abre enorme espaço para a atuação apostólica do fiel cristão.

Nesse contexto, excele a questão dos ministérios não ordenados. Antônio Almeida fez ampla pesquisa sobre eles. Constatou "um inaudito

5 Código de Direito Canônico. 
florescimento de novos ministérios, ou, pelo menos, de serviços eclesiais e de atividades apostólicas, relacionados com a missão da Igreja, assumidos por leigos na América Latina". Apontou alguns exemplos: catequistas populares (Barra do Piraí), delegados de Palavra (Honduras), ministros extraordinários da Eucaristia (Concórdia), ministros extraordinários de diaconia (Apucarana), camponeses missionários (Riobamba). Eles revelam "o clima de liberdade e de responsabilidade", a "referência ao ministério pastoral, com suas funções de animação, discernimento, coordenação" (ALMEIDA, 1989, p. 17-89). As Igrejas locais nessa perspectiva adquirem relevância, já que lhes toca traçar os critérios de criação de tais ministérios.

Embora tenha sido desejo de Paulo VI que mais pessoas, inclusive fiéis cristãos, participassem na escolha dos ministros ordenados, ainda esse processo se faz de maneira pouco transparente, sobretudo dos bispos. Essa questão tem sido abordada por vários analistas. O arcebispo emérito J. Quinn lhe deu uma tratação histórica ampla, ao desocultar a eclesiologia subjacente do atual procedimento e seus inconvenientes (QUINN, 2002, p. 127-151).

A Constituição dogmática Lumen gentium restabelece o diaconato como grau próprio e permanente, facultado a homens casados. É uma experiência que ainda está em andamento e possui já diretrizes consistentes para sua formação, vida e ministério na Igreja no Brasil com experiências em muitas dioceses.

Já há décadas que Igrejas particulares do Brasil têm convocado Assembleias do Povo de Deus, com a liberdade de uma estrutura não prevista no Direito. Dependem muito da caminhada da Igreja particular. Em algumas alcançou-se, com o aval do bispo, significativo avanço a ponto de elas decidirem por voto dos presentes as linhas pastorais mestras da diocese.

João Paulo II ensaiou outro tipo de Sínodo regional. A novidade dessa estrutura não significou necessariamente avanço, já que alguns foram fortemente influenciados pelas instâncias romanas. Mas não deixa de ser uma possibilidade que, em outro momento conjuntural, tem chances de favorecer a colegialidade.

Retomando uma ideia de Mgr. J. Doré, importa mais criar um espírito conciliar ou sinodal do que reunir concílios ou sínodos. Ele propõe a 
passagem de uma Igreja que reúne concílios a uma Igreja que vive conciliarmente (DORÉ, 2005, p. 182, 606).

Muito desafiante para a tradição semita-cristã, marcadamente machista, o papel da mulher. Na prática ela sustenta grande parte das pastorais, no entanto permanecem excluídas do universo das decisões mais importantes e no exercício do ministério ordenado. No momento, a questão está fechada para a Igreja católica. No entanto, há razões graves históricas, antropológicas e ecumênicas que impedem do fechamento total dessa questão.

\section{Evangelização do fenômeno religioso}

Tese: O fenômeno religioso suplanta o papel social da religião. $\mathrm{Na}$ Europa, o Cristianismo se esvai. O seu futuro está na América Latina e depende de sua criatividade e liberdade. Além disso, impõem-se a necessidade teologal do diálogo ecumênico/inter-religioso e o enfrentamento com a cultura midiática.

\section{Fenômeno religioso como saída do Cristianismo}

\section{Natureza}

O fenômeno religioso evidenciou-se na contramão de certa leitura secularizante da década de 1960. Outros interpretaram-no como avatar da secularização. Em todo caso, ele modifica o papel social da religião.

A fragorosa queda do socialismo desprestigiou de tal forma as ideologias que, mesmo continuando elas a existirem nos interstícios da vida social, negam-se tal epíteto. As religiões ocuparam-lhes o vácuo, adquirindo renovada centralidade pública e novas funções sociais.

Tinham perdido com o embate da modernidade o papel de referência englobante da sociedade. A ideologia, a razão, visões seculares do mundo disputavam-lhes a função, deslocando-as para o universo da opção particular do indivíduo. As religiões ofereciam o sentido fundamental 
da realidade, ao apontar-lhe a dimensão transcendente e para além da história. Doravante elas invertem a ótica, interpretando a vida eterna a partir desta. Oferecem propostas para que as pessoas se sintam bem no mundo terrestre.

No seio das religiões imperam o subjetivismo e o pluralismo, altamente estimulados pela globalização das expressões religiosas, inclusive cristãs, entre outras. O Cristianismo sofreu, mais que nenhuma outra religião, o maior impacto em virtude de algumas de suas características. Ele tem a pretensão de ser uma religião universal quanto ao destinatário. O fim dos evangelhos de Mateus e Marcos assinalam com clareza essa perspectiva: "E Jesus lhes disse: "Ide por todo o mundo e pregai o Evangelho a toda criatura" (Mc 16,15). O individualismo e pluralismo minam todo universalismo.

Mais: o Cristianismo alimenta-se da Tradição. Os fatos fundantes situam-se no passado de maneira insuperável de modo que o presente só pode ser-lhe interpretação e nunca criação independente. A cultura midiática pós-moderna provoca a perda da memória cultural, naturalmente também religiosa, com a supervalorização do presente. "Anything goes" - tudo vale. A tradição, que alimenta a fé cristã, se esfuma diante do presentismo exacerbado.

Soa extemporâneo o que a epístola aos hebreus escreveu: "Jesus Cristo, ontem e hoje, é o mesmo e o será para sempre" ( $\mathrm{Hb} 13,8)$. O filósofo A. Sponville reflete bem essa mentalidade. Declara-se ateu, mas considera Jesus Cristo uma pessoa simpática, generosa. É isso. Nada de transcendente (COMTE-SPONVILLE, 2002).

M. Gauchet defendeu a tese de que "O Cristianismo terá sido a religião da saída da religião” (GAUCHET, 1985, p. 133), para traduzir o fim do papel social da Religião. Não quer dizer o fim da crença religiosa já que permanecem pessoas religiosas. "Os deuses sobrevivem, mas seu poder morre. Os crentes não levam a organização religiosa da cidade. Há crentes, mas a sociedade permanece ateia nos princípios e mecanismos" (GAUCHET, 1985, p. 133). Nesse processo, o Cristianismo cumpriu função importante, ao oferecer suporte para a autonomia terrestre.

Olhando para o atual crescimento do pentecostalismo e neopentecostalismo, no mundo evangélico e também no mundo católico, arrisco dizer que o Pentecostalismo é a porta de saída do Cristianismo. Pois ele 
promete a última coisa: o milagre para resolver os problemas imediatos psíquicos e materiais das pessoas. Ao falhar, não resta mais nada do que abandonar definitivamente esse último rincão institucional religioso. Ficarão sentimentos religiosos que brotarão esporadicamente em momentos de crise e tensão na vida. E que tarefas a Igreja Católica tem diante dessa situação?

\section{Tarefas pendentes}

Lentamente se faz consensual dizer que o futuro do Cristianismo está na América Latina. Frase breve, mas de enorme gravidade para a nossa Igreja.

A afirmação funda-se na constatação da agonia do Cristianismo na cultura europeia. Multiplicam-se as pesquisas que confirmam essa asserção. A taxa de natalidade dos europeus baixa fortemente, de modo que nascem mais filhos de migrantes que de nativos, pertencentes a outras tradições religiosas. O ocaso do Ocidente europeu contempla alhures, especialmente na América Latina, o último depositário da fé cristã (JENKINS, 2004).

O Cristianismo cresce em países asiáticos, mas lá predominam majoritariamente outras tradições religiosas. A África está sendo disputada pelos muçulmanos e pratica religiões tradicionais. Sobre, de novo, o continente latino-americano.

A Igreja Católica na América Latina conta com um profundo e enraizado substrato religioso. Cabem diante dele leituras ideológica e pastoralmente diferentes.

Na preparação de Puebla, correntes conservadoras bateram forte nessa tecla. Esse substrato está sendo ameaçado pela cultura ocidental secularizante da qual a teologia da libertação faz parte. Toca-nos defender a religiosidade do povo simples diante da avalanche secularizadora. E isso conduziu a consequências pastorais na linha de conservar sem mais as tradições religiosas, muitas alienantes e até mesmo mágicas. Por esse lado não vemos futuro.

O substrato cristão da cultura latino-americana construiu-se na ambiguidade da histórica. Teologicamente nele se misturam graça e 
pecado, providência divina e fragilidade humana. E a fé permite discernir. A teologia da libertação tem trabalhado muito, na esteira de Paulo Freire, a cultura religiosa popular, resgatando-lhe a força libertadora e purificando-a da ganga impura da alienação.

A modo de exemplo, assinalamos elementos autênticos da religiosidade popular: o primado absoluto de Deus, a esperança inquebrantável diante dos sofrimentos e fracassos, a capacidade sincrética de traduzir para dentro do próprio horizonte elementos fundamentais da fé, a gratuidade, a alegria e a festa em face do domínio da razão instrumental, a perseverança numa práxis sem amargor. Che Guevara consagrara o mote: "Temos que endurecer sem perder a ternura". Síntese de uma cultura latino-americana que está a desaparecer pela brutalidade da violência e das condições de injustiça social.

A ameaça à cultura religiosa latino-americana não vem da secularização, como tal, mas do capitalismo avançado, sustentado pela mídia. Encarna-o a cultura americana de massa que invade os rincões mais longínquos com outros padrões de comportamento. Aí estão o sonho consumista, o culto da aparência, de si mesmo e do físico do corpo, o prazer autocentrado, a substituição das relações pessoais pelas virtuais, a religião como lugar da satisfação das necessidades materiais e afetivas. Todos esses elementos possuem uma face positiva. O discernimento pastoral pede lucidez que foge das críticas conservadoras e reacionárias de pura rejeição da modernidade avançada, mas que lhe aponta os limites e os caminhos a trilhar.

A consciência latino-americana, que está a reagir contra essa avalanche estranha, resgata os próprios valores. L. Boff, depois de mostrar a leitura invasora e colonizadora do Brasil, a partir da praia e das caravelas, assinala o caminho da invenção, apesar de contradições profundas (BOFF, 2000, p. 15-21). "O Brasil é o país onde pode surgir uma nova alternativa”, na expressão de Cristovam Buarque (BUARQUE, 1999, p. 37). Isso implica a construção da cidadania plena e concidadania num projeto da democracia social e popular. Realçam-se alguns traços de nossa cultura: visão relacional da realidade, o jeitinho e malandragem como navegação social, cultura multiétnica e multirreligiosa, criatividade, aura mística, traço lúdico, povo de esperança (BOFF, 2000, p. 67-74, 112-122). 
No referente ao campo religioso, L. Boff chama atenção para o caráter místico e religioso do povo. E vê o futuro religioso do Brasil na criação sincrética de nova espiritualidade ecumênica que conviverá com as diferenças na unidade da percepção do Divino e do Sagrado. Usa a expressão de "nova Roma nos trópicos" (BOFF, 2000, p. 104-107).

A Teologia, em nossas plagas, pensa o sincretismo diferentemente da Teologia europeia e oficial. É conatural ao catolicismo brasileiro um substrato sincrético. P. Sanchis detecta uma estrutura virtualmente sincrética no catolicismo brasileiro. Refere-se "a um habitus (história feita estrutura) de porosidade de identidades. Desde que se entenda bem, essa porosidade pode ser vista como 'sincretismo" (SANCHIS, 1997, p. 105, 112).

Existem várias matrizes de compreensão do sincretismo, desde a simples adição de elementos ou alternância de ritos, sem nenhuma integração até uma refundição e verdadeira inculturação (BOFF, 1981, p. 145171). M. de França Miranda entende que "o sincretismo pode ser considerado não só um produto final, que mostraria então sua concordância ou discordância com determinada tradição religiosa", mas como "um processo, podendo assim ser um fenômeno temporário e não permanente, cujo epílogo permanece ainda uma questão aberta. Enquanto tal, ele poderia ser considerado uma etapa prévia e bastante comum na inculturação da fé, já que este fenômeno é complexo, difícil e longo" (MIRANDA, 2001, p. 120).

Aqui cabe recordar a história. No século XVI para XVII, o missionário M. Ricci (1552-1610) ensaiou uma experiência evangelizadora audaz de inculturação em vários níveis. Vestiu-se como monge budista, assumiu costumes dos sábios confucianos chineses, aprendeu a língua, comportou-se como um chinês. Mostrou enorme respeito e sensibilidade diante das tradições culturais e religiosas dos chineses. Encontrava muitas concordâncias entre a doutrina de Confúcio e o Evangelho. Estudou a fundo os autores e costumes da China com a preocupação de não impor aos novos cristãos pesos inúteis. Foi longe na preocupação com a inculturação. Não temeu usar para o Deus cristão nomes que se encontravam nos escritos do próprio Confúcio. E não viu nos ritos e cerimônias chineses em honra aos antepassados e ao próprio Confúcio nada que ofendesse a fé cristã.

Depois de sua morte, travou-se acirrada discussão que terminou com a proibição por Clemente XI (1704) aos cristãos de participarem nas 
celebrações em honra aos antepassados e a Confúcio. A história da missão chinesa deu uma guinada cuja gravidade até hoje sofremos as consequências. João Paulo II, por ocasião de um Congresso Internacional sobre Matteo Ricci na Pontifícia Universidade Gregoriana, enviou aos participantes uma mensagem. Nela reconhece a justeza dos princípios orientadores da evangelização de Ricci e mostra profundo pesar pelos erros e limites ao causar em não poucas pessoas a impressão de uma falta de respeito e de estima por parte da Igreja católica para com o povo chinês (GARUTI, 2005).

Essa lembrança histórica visa unicamente a evitar que cenas semelhantes se repitam hoje em relação ao processo de inculturação da América Latina. Não se tem mais direito de cometer o mesmo erro, já que o atual nível de consciência não o permite. As Igrejas da América Latina precisam ser mais ouvidas pelas instâncias romanas e até mesmo influenciá-las em vez de serem por elas comandadas com ignorância de causa. Cabe inverter o processo. O movimento sobe das bases para a cúpula em vez de descer de lá para as bases nas questões de inculturação, de criação do imaginário religioso popular com seu universo simbólico e valores próprios. As Igrejas da América Latina podem e devem dar-se essa liberdade e autonomia, afastando-se de subserviências nefastas para uma evangelização inculturada.

\section{Resposta do ecumenismo e diálogo inter-religioso}

\section{Dado fundamental}

O fenômeno religioso quebrou, no Brasil, o monopólio da Igreja Católica. Reinava desde séculos como grande religião enquanto as outras sobreviviam em suas minorias. Com o crescimento da consciência negra e com a difusão das denominações evangélicas pentecostais e neopentecostais, com o firmar-se consciente e de peso das Igrejas do CONIC, a Igreja Católica se viu posta diante de nova postura: desconhecer simulando avestruz, reforçando atitude apologética intransigente ou dialogando. O sopro do Vaticano II enfunou-lhe a vela do diálogo. O espírito ecumênico caracterizou o Vaticano II desde os inícios, expresso na inspiração 
inicial da convocação, na criação do Secretariado para a união dos cristãos e no magistral discurso programático de João XXIII na sessão inaugural.

João Paulo II mostrou, durante o pontificado, nítida preocupação ecumênica por meio de gestos e da Encíclica Ut unum sint. Os incentivos vêm, portanto, do Vaticano II e da prática eclesial subsequente.

\section{Formas concretas de diálogo}

O Pontifício Conselho para o Diálogo Inter-religioso publicou excelente documento sobre o diálogo (PONTIFÍCIO CONSELHO PARA O DIÁLOGO INTER-RELIGIOSO, 1991). Indica-nos quatro formas de diálogo. O diálogo da vida em que as pessoas em espírito de abertura e boa vizinhança compartilham alegrias e tristezas, problemas e preocupações; o diálogo das obras no qual cristãos e os outros colaboram em vista do desenvolvimento integral e da libertação da gente e se põem juntos a serviço de grandes causas; o diálogo dos intercâmbios teológicos pelo qual peritos aprofundam a compreensão da suas respectivas heranças religiosas e apreciam os valores espirituais uns dos outros, trazendo esclarecimentos de conteúdos; e do diálogo da experiência religiosa segundo o qual pessoas radicadas nas próprias tradições religiosas compartilham as riquezas espirituais com outras pela oração, contemplação, fé e caminhos da busca de Deus e do Absoluto.

Esse programa amplo abre espaço para inúmeras iniciativas. A experiência da teologia da libertação significou avanço significativo. Clodovis Boff, na tese doutoral, elaborou as mediações constitutivas do fazer Teologia. A mediação hermenêutica, que interpreta as realidades à luz da Revelação, especifica a Teologia. Na esteira dessa reflexão, permanece tarefa pendente inserir na própria mediação hermenêutica da Teologia latino-americana a exigência de diálogo ecumênico e quiçá inter-religioso. Destarte, a Teologia que não for pensada à luz do ecumenismo e do diálogo inter-religioso não corresponderia ao momento atual.

Durante o Vaticano II, em nome do Secretariado para união dos cristãos, Mgr. De Smet, bispo de Brugges, indicou alguns dos pontos fundamentais para a elaboração teológica de modo ecumênico (LIBÂNIO, 2005, p. 89). 


\section{Outras perspectivas}

A intercomunhão persiste desafiando-nos. A posição oficial atual a entende como ponto de partida. Como participar da mesma Eucaristia se ainda estamos divididos na grave questão da unidade institucional, ministerial? Enquanto essa não se concretizar, posterga-se a intercomunhão. Será que não se pode pensar de outra maneira?

Uma analogia. Os espirituais tradicionais nos diziam que comungávamos, não porque fôssemos dignos, mas para tornarmo-nos dignos pela presença do Senhor. Como pecadores aproximamo-nos da Eucaristia, que é também sacramento da reconciliação, para que, unidos ao Senhor nos purifiquemos, sejamos perdoados e capazes de amar melhor os demais.

Assim, as igrejas separadas, em vez de esperar a união para praticar a intercomunhão, comecem a vivenciá-la como viático para a união. Há sérias razões teológicas para as duas posições. Por brevidade, não exporei o jogo das razões. Então, segundo o probabilismo, não se deveria deixar em aberto tal questão?

A Igreja, ao longo da história, sofreu influência dos modelos políticos vigentes. Aproveitou deles aquilo que cabia dentro de seu arcabouço dogmático. Surgiu em Porto Alegre uma nova experiência política de extrema importância: o Fórum Social Mundial. Nele aparecem elementos bem originais como a confluência plural de inúmeros movimentos e pessoas desde que comunguem no ideal de um "outro mundo melhor possível". Conseguiu pluralismo dentro da unidade de uma utopia. Reduziu ao mínimo o poder dos organizadores de tal modo que ninguém fala em nome do Fórum, embora todos tenham oportunidade de falar no Fórum. Pensar algumas estruturas da Igreja à luz dessa experiência abre possibilidades para inovar aspectos estruturais, canônicos, jurídicos.

\section{Criar condições objetivas para a vida humana}

Tese: No contexto do neoliberalismo globalizado e midiático, cabe à Igreja tarefa de consciência crítica, de opção fundamental pela solidariedade em vista da libertação dos pobres e de ações condizentes com tal opção. 


\section{0 contexto sociocultural}

O Vaticano II realizou-se em momento glorioso do neocapitalismo. Este conseguiu três façanhas que impressionavam os homens da Igreja de então. Levantou a Europa das ruínas da guerra. Inseriu em seu sistema muitos elementos sociais quer para responder positivamente ao desafio do comunismo, quer pela pressão dos partidos socialistas e da luta operária e também pela insistência do Ensinamento Social da Igreja. Conseguiu, sobretudo nos países nórdicos, invejável grau de igualdade social que os países socialistas não implantaram. Entende-se a posição de interesse e até mesmo de certa euforia de meios eclesiásticos em relação a esse tipo de capitalismo social de mercado.

Outra é a situação atual do neoliberalismo. Até mesmo nos países que ontem primaram pelo espírito social, como na Grã-Bretanha, as conquistas sociais foram e estão sendo erradicadas. Que dizer dos países periféricos? Os novos dogmas neoliberais proclamam a centralidade do mercado, a redução do papel do Estado com o minguar do Estado do bem-estar social e com a perda dos direitos sociais das classes subalternas. Impera a ideologia da sanidade, provocando a ruína de tudo o que não se pauta por esse pensamento único.

As consequências em nosso país são bem conhecidas e repetidas por todos os lados: exclusão, novo tipo de pobre, desemprego estrutural, império da mídia sem escrúpulos e ética que açula os desejos de consumismo conspícuo irreprimivelmente. A roda do desejo-tecnologia-consumo faz girar o sistema em velocidade sempre mais acelerada. Aí estamos. Que tarefas cabem à Igreja?

\section{Reposta da Igreja: criar as condições objetivas}

\section{Natureza do Cristianismo}

A Constituição Gaudium et spes estatui o princípio básico de resposta, recuperando o lado mais belo do Cristianismo. Paulo ensinara que em Cristo Jesus não vale a circuncisão nem a incircuncisão, isto é a formalidade ritual, mas a fé que opera pela caridade (Gl 5,6). Tiago dissera que a fé, se não tiver 
obras, por si só está morta (Tg 2,17). E a prática de Jesus pontilhou-se de serviços da caridade. $\mathrm{O}$ evangelho guarda uma eficácia social. Historiadores recentes recordam-nos o lado mais radioso do Cristianismo, a saber, a façanha de caridade que ele desempenhou nos dois milênios desde as coletas de Paulo até o desvelo maravilhoso de Teresa de Calcutá, o zelo insone de D. Hélder Câmara para falar dos já mortos (DELUMEAU, 2003; MOLLAT, 1978).

Contra esse horizonte de fundo, o pórtico da Gaudium et spes proclama a solidariedade fundamental do discípulo de Cristo com alegrias e as esperanças, as tristezas e as angústias dos homens e mulheres de hoje, especialmente os pobres. Princípio revolucionário. E a situação atual?

\section{Situação atual}

Analistas constatam reação neutralizadora do grito profético do Vaticano II por parte de certa orientação da Igreja (BORGMAN, 2005, p. 75). Há dificuldade de pensar um projeto social alternativo em que pese o esforço do Fórum Social Mundial e, de modo especial, do lúcido sociólogo português Boaventura de Sousa Santos.

O impasse de elaborar projeto alternativo decorre de uma evidência. Por mais socialmente injusta que a situação atual seja, ela responde aos interesses do poder dominante. Este carece de qualquer desejo de mudá-la. Antes reage contra as tentativas de fazê-lo. Os pobres, os excluídos, por força de sua condição, dificilmente conseguem pensar e levar a cabo tal elaboração. Eis o impasse: quem pode, não quer; quem quer, não pode.

Cruel crise ética deixa as pessoas insensíveis ao sofrimento alheio, por estarem mergulhadas nos interesses individuais e corporativos. A Câmara dos deputados oferece cabal exemplo de ambos os vícios. No entanto, resta como tarefa prioritária pensar tal projeto. Que papel cabe à Igreja?

\section{Tarefa fundamental: pensar projeto social alternativo}

Dois projetos impõem. Um referente ao conjunto da humanidade e outro especialmente para os pobres. Entre eles vige profunda imbricação. 
Os ricos e os mais pobres, por razões opostas, danificam altamente a natureza e a possibilidade da vida futura para a humanidade. Portanto, os projetos para salvar a humanidade têm de contemplar os pobres, e o projeto em prol dos pobres acarreta benefícios para a humanidade.

Em termos de humanidade, a questão gira em torno do modelo de desenvolvimento atualmente em vigor. Ele é suicida, já que destrói em quantidade cada vez maior a "casa de todos os seres vivos". A natureza tem dado sinais de alarme como o tsunami na Ásia, os tornados nos Estados Unidos Katrina e Rita - que causaram devastações em cidades importantes, como New Orleans. E o degelo do polo, a intensificação do efeito estufa com o consequente aquecimento da crosta terrestre, a destruição da biodiversidade e inúmeros outros problemas agitados pelos ecologistas de todo o mundo.

Várias das últimas obras de L. Boff insistem nesse ponto. Para problemas globais, soluções globais na linha de outro tipo de desenvolvimento (BOFF, 2000; 2003). Indo mais longe, não resolve falar simplesmente de desenvolvimento sustentável, se não se atinge a raiz profunda do problema. Este não está na Terra, nem no ar, nem no calor, nem na água, mas no coração e mente do ser humano. Que ele quer fazer com a Terra? A casa para todos? Ou o bolo cujos grandes nacos são devorados pelos pantagruélicos senhores do dinheiro, deixando as migalhas para os pobres? E no fim, ele acabará para todos.

Não compete à Igreja pensar o lado técnico e político do projeto alternativo. Para isso existem no mundo inteligência suficiente e recursos de pesquisa e simulação de projetos. Cabe-lhe a ingente tarefa de converter os corações e mentes para outra atitude fundamental diante dos bens da terra. L. Boff chamou-a de "ética do cuidado" (BOFF, 2011). P. Arrupe jogava com o binômio simplicidade e sobriedade. A preocupação com a ecologia exige tipo de tecnologia que não danifique a natureza. Pede uma política regional e mundial que proteja o meio ambiente. Desenvolve relações humanas que valorizem a natureza. Demanda agir ético que respeite o patrimônio da humanidade. Cria uma mentalidade que aprecie e admire esse presente de todos. E finalmente alimenta uma espiritualidade e mística que reencontrem com o sonho utópico das primeiras páginas do gênesis, reveladoras do projeto original de Deus (BOFF, 1993).

E para os pobres: Que fazer? Espera-se da Igreja um confronto corajoso e destemido com o neoliberalismo em vista da justiça social nos 
diversos níveis. Neoliberalismo denota exclusão (ASSMANN, 1994), cujo critério se define pelo mercado. Tanto mais excluído quanto menos participa do mercado com compras e vendas. A exclusão diminui à medida que se processa a distribuição de rendas, se implanta a reforma agrária de inspiração social, se gesta uma economia solidária.

A Igreja católica, no Brasil, possui expressivo conjunto de pastorais sociais com os marginalizados, sem-terra, sem-casa, Pastoral Operária, CPT, CIMI. Comissão dos Direitos Humanos, Comissão Justiça e Paz, etc. Todas elas refletem o anseio de uma pastoral da solidariedade. Elas encontram-se diante de excelentes novas possibilidades por meio de parcerias com o Estado, com ONGs, com outras organizações e movimentos sociais nacionais e mundiais. Espaço fecundo para o diálogo ecumênico e inter-religioso. Acrescente-se a aspiração ética que perpassa a sociedade em meio à atual tsulama (tsunami+lama).

O diálogo de parceria exige a consciência da tríplice autonomia dos sujeitos que intervêm, da natureza do projeto e da sociedade em que ele se realiza. As concretizações permitem salutar pluralismo. Deve acompanhar a parceria, uma lúcida revisão crítica permanente, corrigindo os desvios de rota.

Um passo mais à frente. A cultura atual midiática age fortemente por meio de imaginários simbólicos. Haja vista o imbróglio do mensalão. As pessoas acabam pensando, mesmo infundadamente, naquilo que a imprensa incansavelmente repete.

Por que a Igreja não se empenha, com todas as forças midiáticas, na construção de um imaginário social religioso da libertação dos pobres em vez de gastar tanta energia em floreios carismáticos? Reencontraria a lídima inspiração de Jesus e seria presença original e questionadora na atual sociedade na linha da Gaudium et spes.

Pertence ao patrimônio da Igreja do Brasil a teologia-fonte e original da libertação. Possui uma pedagogia libertadora. Conhece, desde longos anos, uma vida religiosa inserida nos meios populares. Pratica a leitura militante e libertadora da Bíblia. Vem produzindo uma teologia feminista corajosa. Desfila uma falange de mártires em prol da causa dos pobres até nos nossos dias com a irmã Dorothy. Organiza Campanhas da Fraternidade de teor social. Escreveu e ainda escreve documentos e declarações 
proféticas. Com tal conjunto dispõe de valioso instrumento para colaborar no projeto social alternativo.

\section{Desafio da Sociedade Pós-Industrial do Conhecimento}

Tese: A sociedade pós-industrial do conhecimento está a levantar sérios desafios à Igreja na sequência do diálogo Igreja-Mundo promovido pelo Concílio Vaticano II.

\section{Definição e natureza}

A sociedade neoliberal midiática não esgota a novidade do momento atual. Entramos na sociedade pós-industrial do saber que se firmará cada vez mais, independentemente do modelo econômico a impor-se. Alimenta-se de outra vertente.

Ela continua o paradigma central da modernidade que conserva a matriz imanentista e de autossuficiência da razão. Interpreta, inclusive o Cristianismo e sua revelação, a partir da dialética da razão (MUCCI, 2005, p. 377). Alguns preferem adicionar-lhe epítetos ou adjetivos entre outros: "sociedade pós-moderna", "do capitalismo avançado", "pós-industrial”, "programada", "pós-materialista”, "tecnotrônica”, "dos serviços", etc. (MASI, 2000, p. 31).

A sociedade pós-industrial do saber define-se por um sistema de produção que depende diretamente da ciência e tecnologia. Sobrevive por meio de conhecimentos tecnocientíficos que gera em vista da produção. Está orientada para a produção de conhecimentos. Põe-se sob o signo da inovação em todos os campos. Desenvolve um tipo de saber criativo. Faz a passagem da produção de bens para a produção de conhecimento. O futuro e a riqueza do país se jogam na geração de informação, de saber, de inteligência. O mote revolucionário pedagógico soa: aprender a aprender (GRANÉS, 2005, p. 75).

A engenharia genética associada à biotecnologia e a informática prometem-se futuro na sociedade secularizada, científica, tecnológica e 
de inovação contínua. Seguem-se consequências para os diversos campos da vida humana.

Estabelece-se íntima vinculação e circularidade entre saber e tecnologia, com sérias repercussões em ambos. Só lá onde se desenvolve altamente a tecnologia se produzem os saberes. E estes, por sua vez, requerem cada vez instrumentos mais sofisticados que só com muito investimento tecnológico se obtêm. Os saberes se geram em vista de avançar a tecnologia do mundo produtivo e a tecnologia possibilita novos saberes. No centro está o capital. Muito capital investido em conhecimento que deve terminar desenvolvendo tecnologias. E estas redundam em maior ganho do capital. Está montado o círculo dos países ricos. Onde se investe menos, há menos: tecnologia, saber, avanço na produção; e, portanto, menos riqueza.

O mundo da organização do trabalho sofre o impacto desse novo jogo. Os pesquisadores constituem grupos de pesquisa. Terminou a era dos geniais criadores individuais. No grupo existem os coordenadores, mas não dão conta sozinhos. Muitos se envolvem na pesquisa. Tal fato exige que, no interior do grupo, reinem liberdade, criatividade, interdependência, trabalho coletivo, transparência e rapidez na comunicação dos dados. Impera nesse campo atroz concorrência com outros grupos. E quem chegar primeiro à descoberta, patenteando-a, faz fortuna. De novo, o capital.

Sob a perspectiva ética, o imperialismo dos países ricos desloca o campo. Mesmo mantendo ainda a propriedade das terras e as indústrias com o controle do capital, privilegiam o domínio e a posse do saber. Obtêm-nos pela via do investimento - produção - e pela patente - controle e posse. Serviu de amostra da luta de foice do futuro a pequena escaramuça simbólica na quebra de patente dos fármacos contra a AIDS.

O mercado não possui entranhas. É impiedoso. Prefere a morte do outro à perda de lucros. Esconde-se sob o anonimato dos números e dos jogos da bolsa. Comete terríveis crimes "invisíveis" e de difícil imputabilidade pessoal. Por isso, seus agentes dormem tranquilos durante a noite da morte de milhões de pessoas.

A influência da sociedade do conhecimento afeta a ética ainda por outro lado. Posta sob o imperativo da inovação, as verdades, os 
conhecimentos, os resultados, as certezas adquirem a conotação relativista. Permanecem até quando outros cheguem para substituí-los. Aumentam-se a responsabilidade e a liberdade dos pesquisadores, já que não se apoiam em tradições anteriores às quais transferi-las. Os pesquisadores deparam com a pluralidade e diversidade de resultados, tendo que administrar tal situação. Impõe-lhes maior clareza na percepção da relação entre finalidades, objetivos da pesquisa e os valores envolvidos. Não se encontram diante de uma matriz estática de valores, mas flexível e em mudança. Distanciam-se do conceito de natureza como dada por Deus como normativa na sua fisicidade para entendê-la como produto da intervenção humana. Sem isso, o progresso científico e tecnológico não se torna factível. A compreensão estoica de uma natureza divina dessacraliza-se. Temos a natureza e a sociedade que queremos. De novo, cresce a responsabilidade humana.

A sociedade do conhecimento modifica a compreensão das relações fundamentais do ser humano. Em relação a si mesmo, as pessoas se entendem mais conscientes, autônomas, senhoras da realidade e menos dependentes de tradições e autoridades externas. Respeito aos outros, crescem as relações virtuais e diminuem as face a face. $O$ outro se torna interessante à medida que seja fonte de troca de informação. $\mathrm{O}$ ignorante não entra no círculo dos relacionamentos. Em relação à sociedade, as pessoas valem pelo grau de conhecimento que possuem. O emprego fica reservado cada vez mais a quem adquiriu grau de escolaridade. As elites prolongam as separações, inventando titulações sempre mais avançadas. Entramos na era dos pós-doutorados, no plural. Multiplicam-se com o beneplácito de órgãos financiadores do Estado. Em face da Transcendência, existe um paradoxo. A mesma racionalidade que reina nos níveis inferiores não vale na religião. Os ateus e agnósticos perfilham os velhos esquemas iluministas. A sociedade do conhecimento ressuscita arquétipos antigos, desenterra deuses e deusas dos panteões pré-cristãos, adere a um sagrado selvagem (BASTIDE, 1997).

Teme-se que cresça na sociedade do conhecimento a luta feroz em torno da obtenção rápida e privilegiada de conhecimentos. Os Estados nacionais já não controlam essa loucura. No máximo propiciam e incentivam a colaboração entre os grupos de pesquisa no seu interior com 
políticas nacionais para a investigação. E nelas estão envolvidos valores. O caminho para a determinação das políticas de pesquisa e valores que as sustentam passa pela discussão democrática, envolvendo a sociedade civil. E existem hoje recursos eletrônicos incríveis para captar os anseios da sociedade e assim democraticamente tomar as decisões.

\section{Tarefas pastorais}

Que tarefas cabem à Igreja nessa sociedade do conhecimento? Ela tende a relativizar os valores, inclusive aqueles considerados autônomos e absolutos pela tradição filosófica clássica. E sobre eles se construía a ética. Corre-se o risco de submetê-los ao arbítrio e aos interesses dos pesquisadores. Muitos deles trabalham comandados pelos objetivos de empresas movidas no mundo capitalista pelo combustível do lucro, do ganho, do mercado. E quando e onde impera o dinheiro, a humanidade é postergada com enormes riscos.

Torna-se tarefa urgente para as religiões investir seriamente na discussão e na construção de uma ética global, como vêm insistindo Küng e Schmidt (2001).

Só assim nos equilibraremos entre um relativismo sem referência a nenhum valor absoluto e um tradicionalismo conservador que absolutiza formas peremptas. Cumpre estabelecer um sistema de valores a partir de critérios em contínua mudança.

A Igreja no contexto da sociedade do saber percebe-se como servidora da verdade e dos valores inspirada pela fé e amor, mostrando-lhes a racionalidade. Ela faz um duplo jogo. Para si, ela se inspira na revelação, na Palavra de Deus. Para fora, fala à racionalidade de modo que mesmo os não crentes tenham condição de entender e aceitar a reflexão sobre a verdade, o bem, os valores. Ela ausculta as vozes das culturas e das diversas racionalidades e desde sua tradição revelada interpreta-as para essas mesmas culturas e racionalidades plurais, sem impor-se em nome de uma instância superior (MUCCI, 2005, p. 378). Apela unicamente pela humanidade de que se julga especialista, como Paulo VI proclamou no discurso na ONU no memorável dia 4 de outubro de 1965. 
A tecnologia da comunicação reina na sociedade do conhecimento. Alimenta-a e atrai-lhe investimentos de modo que tende a crescer. A Igreja tem multiplicado a presença no universo da comunicação participando diretamente na produção e transmissão de programas por meio de canais próprios ou pela ocupação de outros espaços. No Brasil, abriu-se o importante canal da Radiodifusão Comunitária, criada por decreto presidencial em 1998. As CEBs têm tudo para entrar nesse veio de comunicação. Dentro do espírito da lei, que veda proselitismo de qualquer natureza na programação e adota os princípios da pluralidade de opinião e de versão simultânea em matérias polêmicas, divulgando sempre as diferentes interpretações relativas aos fatos noticiados, a Igreja dispõe de amplo espaço para debater temas humanos. Ela o faz de duas maneiras: introduz conteúdos, mesmo que hauridos na revelação, por valerem pela sua humanidade e desperta nas pessoas a capacidade crítica diante dos problemas. Pelos conteúdos ensina, pela posição judiciosa cria consciência crítica para além de um dado material concreto.

Com efeito, independentemente do fato de possuir ou não meios próprios, existe a tarefa pedagógica de formar a consciência crítica do fiel. A pedagogia da libertação dispõe de ampla experiência nesse campo, desde os inícios na esteira luminosa de Paulo Freire. As culturas de massa, midiática e virtual, vêm influenciando cada vez mais as mentes da nova geração. Têm produzido, de um lado, gigantesco acesso ao mundo da informação e, de outro, diminuição da capacidade reflexiva e simbólica. Por isso, constitui-se prioridade básica, segundo o programa sugerido pelo Relatório da Unesco de J. Delors, educar as pessoas na arte de "aprender a conhecer", de "aprender a pensar".

A mídia se transformou no areópago dos tempos modernos. Lugar privilegiado para a pastoral de massas. Se não serve como ambiente da vivência do mistério, ao menos nela se lançam as palavras ao vento e cairão nos terrenos mais diversos e frutificarão para além de nossa percepção.

Ainda nesse campo, a Internet permite outro tipo de presença pastoral. Conjuga dois elementos paradoxais. Pela multidão de sites e pela amplíssima informação, insere-nos na sociedade da cultura de massa. Não há limites no tipo de informação, desde as coisas mais sérias e santas até as mais perversas e provocadoras. É o lado de massa. No entanto, ela tem uma face individualizante, personalista. Permite-nos da solidão do próprio 
computador comunicar-nos com qualquer pessoa, escondendo-nos sob algum pseudônimo ou entrando em relação verdadeiramente pessoal. A pastoral do atendimento, da orientação espiritual, de cursos especializados tem nela excelente recurso, embora sempre com risco e ambiguidade.

$\mathrm{O}$ fato de ser uma sociedade do conhecimento não significa que se vivam momentos luminosos de cultura. Pelo contrário, atravessa-a uma contradição. De um lado, forma-se exigente e excelente minoria de pessoas em todos os setores. Universidades de renome e Institutos de excelência preparam a intelligentsia da sociedade. Fazem as ciências e a tecnologia desenvolverem-se. Assumem o papel hegemônico de dirigir o modo de pensar das grandes massas. Aí estão a alta administração, os executivos com MBA (Master in Business Administration), os cientistas de ponta, o tecnólogos de requintada sofisticação, enfim a "intelligentsia” do país. Quando esta navegava nos idos medievais em águas da filosofia clássica e da teologia, a Igreja clerical se sentia em casa, porque ela mesma detinha o monopólio cultural. À medida que as ciências se distanciaram da matriz cristã e afirmaram sua autonomia, iniciaram-se os conflitos entre fé e ciência, fé e razão que perduram até hoje. Em alguns casos, recrudesceram.

Nesse campo aparece a importância de ter um laicato de alto nível e de representatividade eclesial para dialogar, como cristãos, com as ciências e tecnologias. Tarefa que o Concílio encetou na Gaudium et spes, que João Paulo II reafirmou na Encíclica Fides et ratio, mas que está longe de ser satisfatório para os dois lados.

\section{Problemas das migrações}

Tese: As migrações se tornam fenômeno crescente no mundo inteiro e no interior do Brasil a desafiar a pastoral da Igreja.

\section{Análise}

Centenas de milhões de pessoas se movem dentro dos países e para fora deles em migrações crescentes. Surgem duas perguntas óbvias. Por que 
deixam a própria terra? E por que buscam outra terra e qual ela é? Jogam fatores de expulsão e de atração. Qualquer análise concreta nos levaria longe porque ambos os fatores são plurais. Fica a pergunta para o estudo dos casos particulares de cidades, estados e do próprio país. O Brasil conheceu, em outros momentos, a descida dos nordestinos para São Paulo. Agora presencia o êxodo massivo para os Estados Unidos, Portugal, outros países da Europa, Japão. Que há por trás dessas ondas migratórias? Que razões objetivas, verdadeiras e que razões ilusórias? Campo que merece ainda maiores considerações com pesquisas e sérias interpretações.

Saltam aos olhos dois conjuntos de fatores. Do lado objetivo, encontramos a pobreza, a falta de futuro em que se está, a crescente segregação econômica, racial e religiosa, os conflitos internos regionais. Do lado subjetivo, faíscam sonhos de riqueza, do Sul maravilha, dos Estados Unidos de dinheiro fácil e abundante, de amealhar rapidamente recursos para resolver definitivamente a questão da habitação e outras exigências básicas. Pobreza e sonho, falta de futuro e ilusão de futuro radioso. É a fome do ser humano de "pão e beleza", como Frei Betto chamou (FREI BETTO, 1991).

\section{Desafio pastoral}

E o desafio pastoral? Breve palavra. Se as regiões do Sul do Brasil, de migração alemã e italiana, conservaram a fé católica ou luterana, isso dependeu do fato de que vieram pastores com os imigrantes e criaram verdadeiras colônias religiosas fervorosas.

Nos dias de hoje, o fluxo migratório no Brasil tem-se modificado muito. Levas de migrantes do Sul têm ido para o Oeste e Norte do país. E nem de longe o clero, os religiosos, as estruturas da Igreja os acompanham. Por isso, não se formam comunidades eclesiais.

Com o avanço dos estudos da geografia, um primeiro passo na pastoral do migrante consiste no estudo do mapa migratório do Brasil e a partir daí traçar as linhas pastorais.

Estamos em terreno relativamente novo. As migrações de hoje diferenciam-se bastante das de outrora sob o aspecto socioeconômico e psicossocial. E, por isso, requer critiavidade pastoral. 
A crescente integração latino-americana trará migrações dos países circunvizinhos, exigindo já outro tipo de assistência pastoral. Enquanto caminhamos lentamente ou dormimos, as denominações evangélicas pentecostais e neopentecostais ocupam rapidamente esses espaços. Nem sempre para o bem das pessoas. Não nos movem razões proselitistas, mas unicamente de lealdade evangélica e amor aqueles que caem presa fácil de distorções religiosas.

\section{Conclusão}

Muitas outras tarefas permanecem pendentes. Mas o texto já vai longe. Fiquemos por aqui com uma última pergunta: será que um novo concílio viria despertar-nos para novas tarefas?

As opiniões se dividem. Comparando as duas conjunturas, a em que o Vaticano II foi convocado e a de hoje, inclino-me a pensar na inoportunidade de novo Concílio. Há questões técnicas por causa do número muito maior de bispos (DORÉ, 2005, p. 181). Mais: um Concílio só de Bispos já não responde à consciência eclesial que gostaria de ver nele, como reais participantes, leigos e leigas. E então como fazê-lo a não ser em forma representativa, mas não coletiva? E outros perguntam se o que está em jogo não é muito mais que a Igreja católica, mas o próprio Cristianismo. Então um Concílio teria que ser convocado pelo conjunto das Igrejas cristãs (BARROS, 2003, p. 39-54). E outros ainda vão mais longe: não está em perigo a própria sobrevivência da humanidade tanto pela destruição ecológica quanto pela miséria de milhões? E por que não pensar grande e investir, como Igreja, em organizações, congressos, assembleias mundiais que se preocupam com tal problemática?

Pesa ainda mais outra razão. A conjuntura da década de 1960 anunciava grandes mudanças e havia entre bispos e teólogos uma plêiade de primeira grandeza. Por isso, foi possível uma obra daquele fôlego. Esse início de milênio, em termos culturais e de movimentos, não parece prenhe de esperança. Atola-se em mediocridade perigosa. Um Concílio nessa situação arrisca significar um retrocesso em vez de um avanço. Permanece, portanto, o desafio de promover uma recepção criativa do Vaticano II. 
Medellín foi brilhante exemplo. Se não se faz possível avançar em todos os setores, que, pelo menos, em alguns deles, surjam iniciativas inovadoras. Dessa esperança, vivemos.

\section{Referências}

ALMEIDA, A. J. de. Os ministérios não ordenados na América Latina. São Paulo: Loyola, 1989.

ARENDT, H. Eichmann em Jerusalém: um relato sobre a banalidade do mal. São Paulo: Companhia das Letras, 2001.

ASSMANN, H. Crítica à lógica da exclusão: ensaios sobre Economia e Teologia. São Paulo: Paulus, 1994.

BARROS, M. Uma nova primavera para a Igreja. Perspectiva Teológica, n. 35, p. 39-54, 2003.

BASTIDE, R. Le sacré sauvage: et autres essais. Paris: Stock, 1997.

BENEDETTI, L. R. O "Novo Clero": Arcaico ou moderno? Revista Eclesiástica Brasileira, n. 233, p. 88-126, 1999.

BEOZZO, J. O. O Concílio Vaticano II: etapa preparatória. In: LORSCHEIDER, A. et al. Vaticano II. 40 anos depois. São Paulo: Paulus, 2005. p. 9-37.

BOFF, L. Igreja, carisma e poder. Petrópolis: Vozes, 1981.

BOFF, L. Ecologia, mundialização, espiritualidade. São Paulo: Ática, 1993.

BOFF, L. Saber cuidar: ética do humano-compaixão pela terra. Petrópolis: Vozes, 1999.

BOFF, L. Depois de 500 anos: que Brasil queremos? Petrópolis: Vozes, 2000.

BOFF, L. Princípio de compaixão e cuidado. Petrópolis: Vozes, 2001.

BOFF, L. Ética e eco-espiritualidade. Campinas: Verus, 2003. 
BORGMAN, E. Gaudium et spes: o futuro esquecido de um documento revolucionário. Concilium, v. 4, n. 312, p. 75-84, 2005.

BUARQUE, C. A segunda abolição. Rio de Janeiro: Paz e Terra, 1999.

CARTA ENCÍCLICA do Papa João XXIII Pacem in Terris. A Paz de todos os Povos na base da Verdade, Justiça, Caridade e Liberdade, n. 52.

CONGAR, Y. Mon journal du concile. Paris: Éd. du Cerf, 2002. v. 2.

COMTE-SPONVILle, A. A. Apresentação da filosofia. São Paulo: M. Fontes, 2002.

CROSSAN, J. D. O Jesus histórico: a vida de um camponês judeu do Mediterrâneo. Rio de Janeiro: Imago, 1994.

CROSSAN, J. D. Jesus: uma biografia revolucionária. Rio de Janeiro: Imago, 1995.

DELUMEAU, J. Guetter l'aurore: un Christianisme pour demain. Paris: B. Grasset, 2003.

DORÉ, J. O Vaticano II hoje. Concilium, v. 4, n. 312, p. 172-184, 2005.

FREI BETTO. Fome de pão e de beleza. São Paulo: Siciliano, [19-?].

GARUTI,A.Matteo Ricci:a missão conformeoVaticanoII, no séculoXV. Revista Mundo e Missão. Disponível em: <http://www.pime.org.br/mundoemissao/ historiaricci.htm>. Acesso em: 29 dez. 2005.

GAUCHET, M. Le désenchantement du monde: une histoire politique de la religion. Paris: Gallimard, 1985.

GRANÉS, M. Hacia una sociedad del conocimiento. Alternativas, v. 12, n. 29, p. 75-90, 2005.

JENKINS, P. La terza Chiesa: Il cristianesimo nel XXI secolo. Roma: Fazi, 2004. KÜNG, H. Projeto de ética mundial: uma moral ecumênica em vista da sobrevivência humana. São Paulo: Paulinas, 1992. 
KÜNG, H. Uma ética global para a política e a economia mundiais. Petrópolis: Vozes, 1999.

KÜNG, H.; SCHMIDT, H. Uma ética mundial e responsabilidades globais: duas declarações. São Paulo: Loyola, 2001.

LIBÂNIO, J. B. Concílio Vaticano II: em busca de uma primeira compreensão. São Paulo: Loyola, 2005.

MASI, D. de. A sociedade pós-industrial. 3. ed. São Paulo: SENAC, 2000.

MELLONI, A. O que foi o Vaticano II? Breve guia para os juízos sobre o concílio. Concilium, v. 4, n. 312, p. 34-46, 2005.

MIRANDA, M. de F. Inculturação da fé: uma abordagem teológica. São Paulo: Loyola, 2001. p. 34-46.

MOLLAT, M. Les pauvres au moyen âge: étude sociale. Paris: Hachette, 1978.

MUCCI, G. Recenti opinioni sul futuro della chiesa. CivCatt, v. 156, n. 3725, p. 377-385, 2005.

OLIVEIRA, P. A. R. de. CEB: unidade estruturante de Igreja. In: BOFF, C. et al. As comunidades de base em questão. São Paulo: Paulinas, 1997. p. 162-176.

PONTIFÍCIO CONSELHO para o diálogo inter-religioso. Diálogo e Anúncio de 19 de maio de 1991. Disponível em: <http://www.vatican.va/roman_curia/pontifical_councils/interelg/documents/rc_pc_interelg_doc_19051991_dialogue-andproclamatio_po.html>. Acesso em: 18 out. 2011.

QUeIRUGA, A. T. O Vaticano II e a Teologia. Concilium, v. 4, n. 312, p. 25-37, 2005.

QUINN, J. R. Reforma do Papado: indispensável para a unidade cristã. Aparecida: Ed. Santuário, 2002.

RATZINGER, J.; MESSORI, V. A fé em crise: o cardeal Ratzinger se interroga. São Paulo: EPU, 1985.

SANCHIS, P. O campo religioso contemporâneo no Brasil. In: ORO, A. P.; STEIL, C. A. (Org.). Globalização e religião. Petrópolis: Vozes, 1997. p. 103-115. 
SANTOS, B. de S. Do pós-moderno ao Pós-colonial e para além de um e outro. In: CONFERÊNCIA DE ABERTURA DO CONGRESSO LUSO-AFRO-BRASILEIRO DE CIÊNCIAS SOCIAIS, 8., 2004, Coimbra. Anais... Coimbra: Congresso LusoAfro-Brasileiro de Ciências Sociais, 2004.

TEIXEIRA, F. Os encontros intereclesiais de CEBs no Brasil. São Paulo: Paulinas, 1996.

URQUHART, G. A armada do papa: os segredos e o poder das novas seitas da Igreja Católica. Rio de Janeiro: Record, 2002.

Recebido: 23/11/2011

Received: 11/23/2011

Aprovado: 02/02/2012

Approved: 02/02/2012 